\title{
Differential susceptibilities of human lung, breast and skin cancer cell lines to killing by five sea anemone venoms
}

Ramezanpour M (1), Burke da Silva K (2), Sanderson BJS (3)

(1) Department of Medical Biotechnology, School of Medicine, Flinders University of South Australia, Adelaide, Australia; (2) School of Biological Sciences, Flinders University of South Australia, Adelaide, Australia; (3) Department of Medical Biotechnology, School of Medicine, Flinders University of South Australia, Adelaide, Australia.

\begin{abstract}
Although sea anemones are well known for being rich sources of toxins, including cytolysins and neurotoxins, their venoms and toxins have been poorly studied. In the present study, the venoms from five sea anemones (Heteractis crispa, Heteractis magnifica, Heteractis malu, Cryptodendrum adhaesivum and Entacmaea quadricolor) were obtained by the milking technique, and the potential of these venoms to kill cancer cells was tested on three cell lines (A549 lung cancer, T47D breast cancer and A431 skin cancer). The total protein level in the crude extract was determined by the bicinchoninic acid (BCA) protein assay. The cytotoxicity on different cell lines was assayed using the 3-(4, 5-dimethylthiazol-2yl)-2, 5-diphenyltetrazolium bromide (MTT) assay which measures survival based on the detection of mitochondrial activity and by the crystal violet assay, which measures survival based on the ability of cells to remain adherent to microplates. The results indicate that the sea anemone venom is cytotoxic to human cancer cells. The A549 cell line was the most sensitive of the cell lines tested with a significant reduction in viability observed at $40 \mu \mathrm{g} / \mathrm{mL}$. H. malu, C. adhaesivum and E. quadricolor had a significant inhibitory effect on A431 cells. Furthermore, H. malu and C. adhaesivum had a significant inhibitory effect on T47D cell line at $40 \mu \mathrm{g} / \mathrm{mL}$. In conclusion, the sea anemone venoms tested have the potential to be developed as anticancer agents.
\end{abstract}

Key words: sea anemone venoms, cytolysin, cancer cell line.

\section{INTRODUCTION}

Sea anemones are marine-dwelling, solitary invertebrates belonging to the phylum Cnidaria and the class Anthozoa (1). Sea anemones were named after a terrestrial flower and have a central mouth surrounded by tentacles in a symmetrical structure (2). There are symbiotic relationships between some sea anemones and some clown fish (3). In nature, clown fish consistently cohabitate with only ten anemone species.

A few sea anemone species can cause a mild to severe sting that leads to pain, erythema, ulcer and sometimes necrosis, for example, Anemonia sulcata and Phyllodiscus semoni which are dangerous to humans $(4,5)$.

It is fortunate that a relatively small number of sea anemone species are harmful to humans and that the stinging incidence is low, perhaps because sea anemone nematocysts are often too small to penetrate far into skin $(6,7)$.

It is well known that, compared to other cnidarians (typically jellyfish toxins), sea anemone toxins are relatively stable (5). Therefore, a number of toxins from various species of sea anemones have been isolated and extensively characterized (8).

Sea anemones possess a variety of peptide 
and protein toxins that affect ion channels in electrically excitable cells. The anemone toxins bind to the site on sodium channels and slow down the process of sodium inactivation. Some anemones also contain smaller peptide toxins that selectively block specific potassium channels. Most anemones also contain potent cytolytic proteins called actinoporins, which permeabilize cell membranes and ultimately cause cell death $(6,9)$. The use of toxins and venoms as the basis of natural products can provide new biomedical research tools and unique molecular models for designing anticancer drugs $(10,11)$. Structural analysis of the $\mathrm{K}$ channel peptide toxin from sea anemones would provide basic information which could allow the designing of immunosuppressant drugs (11).

The cytotoxic and cytolytic properties of two anemone species - both of which act as hosts to clown fish, Stichodactyla mertensii and Stichodactyla haddoni - were measured in vivo using Artemia salina nauplii. Both sea anemone extracts showed significant cytotoxicity with LC $50=0.65 \mathrm{mg} / \mathrm{mL}$ and LC $50=0.90 \mathrm{mg} / \mathrm{mL}$, respectively (12).

In a study of the cytotoxic activity of Aiptasia mutabilis, complete necrosis of a monolayer of renal monkey Vero cells was reported one hour after treatment with a ten-fold dilution of the nematocyst constituting $0.17 \mathrm{mg} / \mathrm{mL}$ of protein (13).

Recently, Fedorovetal.(14) reported anticancer effects of actinosporins from $H$. crispa venom and a cytotoxic effect against human tumor cells. The result demonstrated the potent cytotoxic activity of actinosporins $\left(\mathrm{IC}_{50}=1-5 \mathrm{nM}\right)$ against human cancer cell lines. Following these experiments, the goal of the current study was to determine the susceptibility of three human cancers cell lines to killing by five different sea anemone venoms.

\section{MATERIALS AND METHODS}

\section{Reagents}

3-(4, 5-dimethylthiazol-2-yl)-2, diphenyltetrazolium bromide (MTT, 97.5\%), crystal violet powder, acetic acid and sodium dodecyl sulfate (SDS, 99\%), bicinchoninic acid solution, copper (II) sulfate pentahydrate solution $4 \%(\mathrm{w} / \mathrm{v})$, and protein standard solution (bovine serum albumin) were purchased from Sigma-Aldrich (USA). Methanol was purchased from Merck (Germany). MTT was dissolved in phosphate buffered saline (PBS) at $5 \mathrm{mg} / \mathrm{mL}$, then filtered $(0.2 \mu \mathrm{m})$ to sterilize before use and stored at $-20^{\circ} \mathrm{C}$.

\section{Cell Line and Cell Culture}

The human adherent skin cancer A431 cell line, breast cancer T47D cell line, and lung cancer A549 cell line were obtained from American Type Culture Collection (ATCC). The A431 cell line was maintained in DMEM medium (Sigma-Aldrich, USA) whereas the T47D and A549 cell lines were maintained in RPMI 1640 (Trace Biosciences, Australia), with $10 \%$ fetal bovine serum (FBS Trace Biosciences, Australia) and 1\% penicillin/ streptomycin (Thermo Scientific, Australia). Cells were seeded in tissue culture flasks and incubated at $37^{\circ} \mathrm{C}$ in a $5 \% \mathrm{CO}_{2}$ fully humidified incubator. All cell lines were subcultured every 3-4 days.

\section{Venom Extraction}

Anemones ( $H$. crispa, $H$. magnifica, $H$. malu, C. adhaesivum and E. quadricolor) were collected from the Great Barrier Reef near Cairns Queensland, Australia, and housed in the marine aquaria in the animal house at Flinders University. Anemones were kept within a tropical sea water aquarium and fed weekly with prawn, but then fasted for a week prior to venom collection. A crude extract was obtained by milking, a technique that does not appear to cause serious harm to the anemone (15). Crude venom was obtained by transferring sea anemone from an aquarium into a clean plastic aquarium bag where the tentacles were massaged gently to release venoms. Each individual was milked by gently massaging tentacles one to three times. Venom samples were lyophilized and stored at $-80^{\circ} \mathrm{C}$ until required for assays. When needed, the lyophilized venoms were dissolved in Milli-Q water at $100 \mathrm{mg} / \mathrm{mL}$.

\section{Protein Determination}

The total level of protein in the crude extract 5 was determined by using bicinchoninic acid (BCA) protein assay $(16,17)$. Bovine serum albumin (BSA) solutions were used as protein standards at the following concentrations: 1000, $800,600,400,200$ and $0 \mu \mathrm{g} / \mathrm{mL}$, each obtained from a $20 \mathrm{mg} / \mathrm{mL}$ stock. Twenty-five microliters of each standard was added to a 96-well flat-bottom plate in triplicate, or $25 \mu \mathrm{L}$ of each sample to be 
analyzed. Bicnichoninic acid (Concentration A) and copper II sulfate (Concentration B) were mixed at a ratio of 50:1 and added to each well at a volume of $200 \mu \mathrm{L}$. The plate was covered and incubated at $37^{\circ} \mathrm{C}$ for 30 minutes. The $\mathrm{OD}$ was determined on a spectrophotometric plate reader at $562 \mathrm{~nm}$ (Model 550 with Micro plate Manager Software, BioRad, USA).

\section{Bioassays}

The cytotoxicity effects of crude extracts were determined using the MTT assay (18-19). Cells were seeded at $10^{4}$ into each well in $100 \mu \mathrm{L}$ in quadruplicate wells of 96 -well flat-bottom plates and incubated for 24 hours $\left(37^{\circ} \mathrm{C}, 5 \% \mathrm{CO}_{2}\right)$ to allow attachment of cells. Then the media were replaced with $180 \mu \mathrm{L}$ of fresh media plus $20 \mu \mathrm{L}$ of each extract (H. crispa, H. magnifica, H. malu, C. adhaesivum and E. quadricolor). The cells were incubated with each extract at final protein concentrations of $0.1,1,10$, and $40 \mu \mathrm{g} / \mathrm{mL}$ (equal to $2.5,25,250$ and $1000 \mu \mathrm{g} /$ $\mathrm{mL}$ of mass concentration) for 24,48 and 72 hours. One hundred microliters of MTT at a final concentration of $0.5 \mathrm{mg} / \mathrm{mL}$ (a soluble tetrazolium salt) was added to each well. After four hours, $80 \mu \mathrm{L}$ of $20 \%$ SDS was added to each well, plates were incubated overnight in the dark at room temperature. The plates were read on an ELISA plate reader (BIO-TEK Instruments Inc., USA) using a wavelength of $570 \mathrm{~nm}$, with a reference wavelength of $630 \mathrm{~nm}$.

The crystal violet assay is designed to obtain quantitative information about the relative density of adherent cells (20,21). Briefly, after treatment, the medium was removed, $50 \mu \mathrm{L}$ of $0.5 \%$ of crystal violet in $50 \%$ methanol was added to each well and incubated for ten minutes at room temperature to stain cell nuclei, and subsequently excess dye was washed out gently by distilled water. The plate was allowed to dry overnight then $50 \mu \mathrm{L}$ of $33 \%$ acetic acid was added to de-stain cells for ten minutes. The OD at $570 \mathrm{~nm}$ was measured on an ELISA plate reader (BIO-TEK Instruments Inc., USA) with $630 \mathrm{~nm}$ as the reference wavelength.

Absorbance values from the MTT and crystal violet assays were converted to cells/well using a standard curve run with each experiment (19). Results from the cell viability assays were expressed as percentages of untreated controls.

\section{Statistical Analysis}

Experiments were conducted at least three independent times $(n=3)$. The effects of sea anemone extract on viability of A431, T47D, and A549 cell lines were analyzed by one-way analysis of variance and post-hoc Tukey test, with significance defined as $p<0.05$. All data were analyzed using SPSS software (version 18.0).

\section{RESULTS}

Induction of cell hazard was determined by two methods, MTT (relative viability) and Crystal violet assay (relative cell number). Venom extracts (H. magnifica, H. crispa, H. malu, E. quadricolor and C. adhaesiuvm) were tested on the A549 lung cancer, A431 skin cancer and T47D breast cancer cell lines.

The total protein concentration in the crude extracts of $H$. magnifica and H. crispa was $400 \mu \mathrm{g} /$ $\mathrm{mL}$. The respective concentrations of $H$. malu, $C$. adhaesivum and E. quadricolor were $598 \mu \mathrm{g} / \mathrm{mL}$, $1387 \mu \mathrm{g} / \mathrm{mL}$ and $1176 \mu \mathrm{g} / \mathrm{mL}$.

A549 was susceptible to all extracts tested in viability and cell number (Figure 1). In the MTT assay, all of the extracts significantly reduced viability of the A549 cell line to $40 \mu \mathrm{g} / \mathrm{mL}$ (Figure $1)$. In the crystal violet assay $H$. magnifica, $H$. malu, E. quadricolor and C. adhaesivum had significant inhibitory effect on A549 cells, although $H$. crispa did not show any significant effect. The toxic effects of the extracts by the MTT assay were slightly increased for E. quadricolor at 24 and 72 hours. Toxic effects for H. crispa were slightly elevated at 24, 48 and 72 hours, although there was no clear time-dependent effect for $C$. adhaesivum, H. magnifica and H. malu on A549 cells (Figure 1).

H. magnifica and H. crispa and E. quadricolor had no significant effect on the T47D breast cancer cell line; however, $H$. malu, C. adhaesivum had a significant inhibitory effect on cell number following treatment of this cell line (Figure 2). A significant reduction was observed at the dose of $40 \mu \mathrm{g} / \mathrm{mL}$. The effects on cell viability (MTT assay) were less marked than those on cell number (crystal violet assay) (Figure 2). A significant time-dependent effect was found by the crystal violet assay at 24, 48 and 72 hours for $\mathrm{H}$. malu on the T47D cell line.

In A431 cells, treatment with $H$. malu, $C$. 

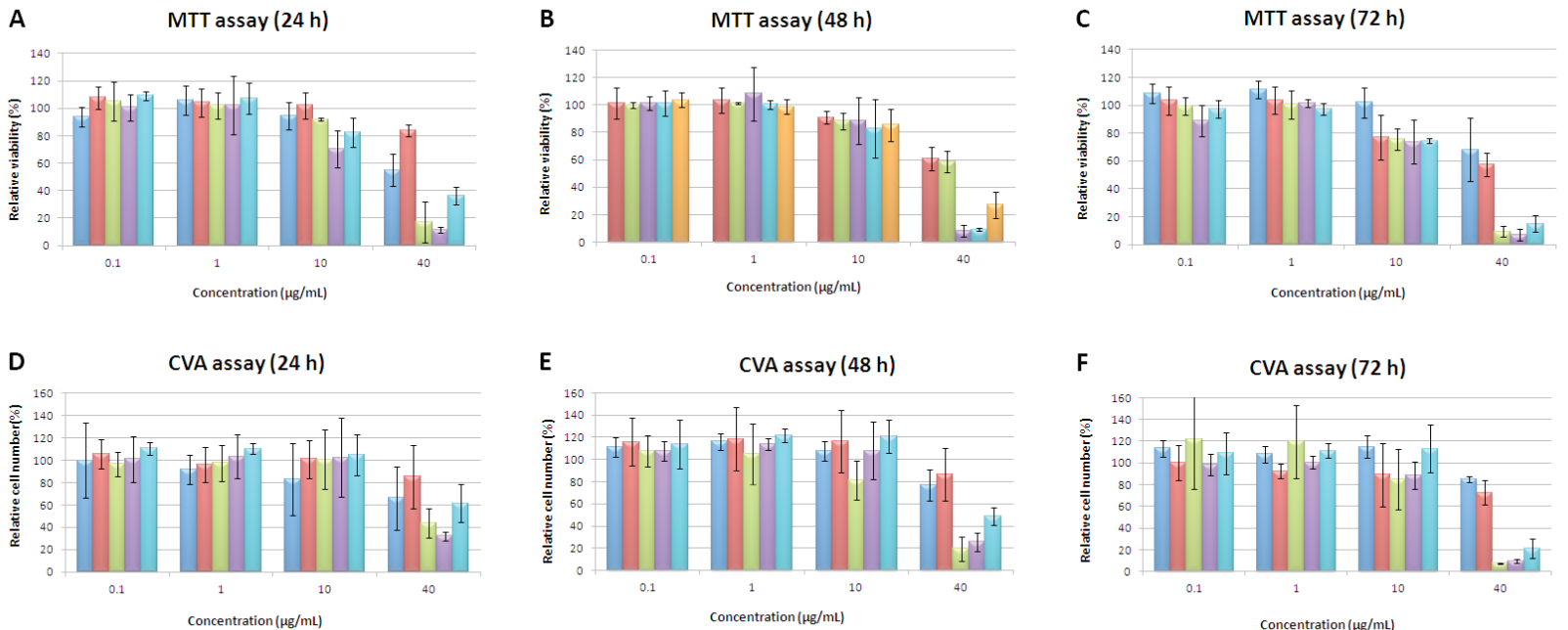

Figure 1. Cell viability percentage of A549 cells was estimated by MTT and cell number by crystal violet assay in 96-well plates following 24-, 48- or 72-hour exposure to H. magnifica, H. crispa, H. malu, C. adhaesivum and $E$. quadricolor (each represented individually as bars from left to right respectively). Data is shown as mean \pm SEM of three separate experiments. Treatments significantly different from the untreated control at $\mathrm{p}<0.05$ are presented as *
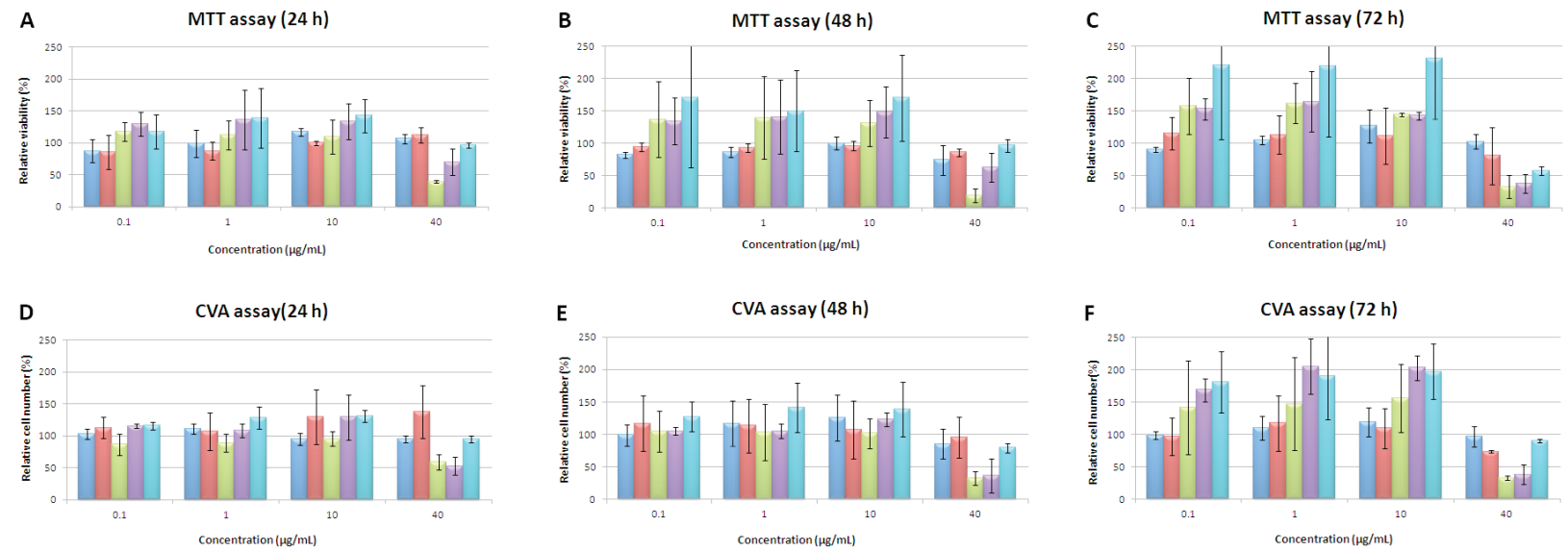

Figure 2. Effect of H. magnifica, H. crispa, H. malu, C. adhaesivum and E. quadricolor (each represented individually as bars from left to right respectively) on growth of T47D cells measured by the MTT and crystal violet assays. Data are shown as mean \pm SEM of three separate experiments. Treatments significantly different from the untreated control at $p<0.05$ are presented as *.

adhaesivum and E. quadricolor reduced viability at the dose of $40 \mu \mathrm{g} / \mathrm{mL}$ in both assays (Figure 3). H. magnifica had a significant inhibitory effect on proliferation of A431cells after 24 and 72 hour treatment using the MTT assay; but there was no significant effect detected by the crystal violet assay (Figure 3 ). In both assays, all the extracts, except for $H$. crispa, presented a significant time-dependent response on A431 cells with decreasing survival as the exposure time increased (Figure 3).

\section{DISCUSSION}

Most investigations on sea anemones have focused on purification and isolation of venom. Research into the potential of sea anemone venoms to act as anticancer agents has been 

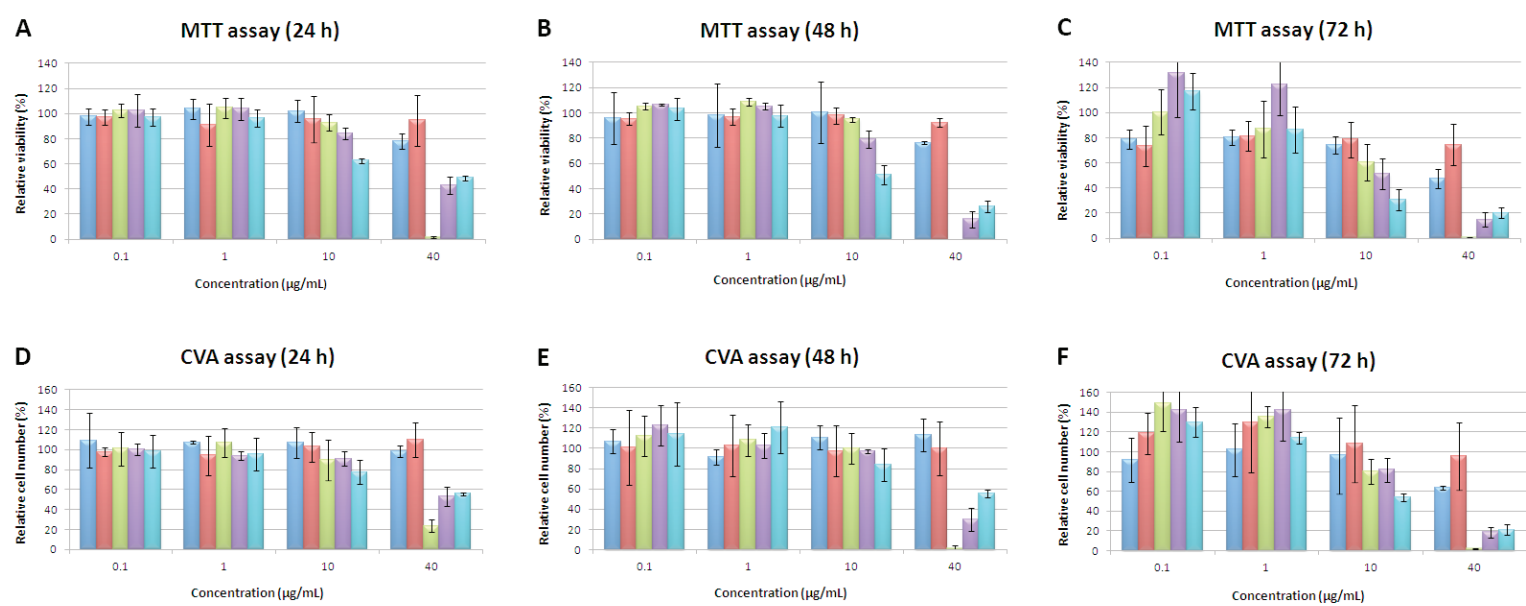

Figure 3. Cytotoxic effect of $H$. magnifica, H. crispa, H. malu, C. adhaesivum and E. quadricolor (each represented individually as bars from left to right respectively) on the A431 cell line measured by the MTT and crystal violet assays. Data are shown as mean \pm SEM of three separate experiments. Treatments significantly different from the untreated control at $p<0.05$ are presented as *.

poorly studied. In the current study, the potential of sea anemone venoms (Heteractis magnifica, Heteractis crispa, Heteractis malu, Cryptodendru adhaesivum and Entacmaea quadricolor) to kill cancer cells, was tested on three cancer cell lines: A549 lung cancer, T47D breast cancer and A431 skin cancer. The cell viability was assessed by the MTT assay which is based on the functioning of mitochondrial dehydrogenase enzyme, while the crystal violet assay stains the nuclei of viable adherent cells, so that the assays measure different endpoints. E. quadricolor and $H$. crispa did not have a significant effect on T47D and A549 cells, respectively, by the crystal violet assay.

In previous studies assessing the toxicity of $B$. caissarum venom on human glioblastoma U87 (p53 mutant) or A172 (p53 wild type) cells, when treated with the toxin, a reduction in viability was observed at the dose of $1000 \mu \mathrm{g} / \mathrm{mL}$, which indicates a toxicity similar to those of $H$. magnifica and $H$. crispa toxins in the present study, which had a significant effect at $40 \mu \mathrm{g} / \mathrm{mL}$ protein (equal to $100 \mu \mathrm{g} / \mathrm{mL}$ of mass concentration) (22).

The new peptide toxins (gigantoxins) were isolated from the sea anemone Stichodactyla gigantean (20, 23, 24). Gigantoxins II and III were potently lethal in crabs with respective $\mathrm{LD}_{50}$ levels of 70 and $120 \mu \mathrm{g} / \mathrm{kg}$. Moreover, Gigantoxin I caused rounding of almost all A431 cells when examined by phase-contrast microscopy. Consistent with this study, significant reduction of A431 cell viability was provoked by treatments with $40 \mu \mathrm{g} / \mathrm{mL}$ of $H$. malu, H. magnifica, $C$. adhaesivum or E. quadricolor toxins.

Two cytolysins, magnificalysins I and II, were purified from $H$. magnifica. Both of these venoms present hemolytic and lethal activities. Hemolysis of magnificalysins I was measured at $3.6 \times 10^{4} \mathrm{HU} /$ $\mathrm{mg}$, versus $3.3 \times 10^{4} \mathrm{HU} / \mathrm{mg}$ for magnificalysins II. Their $\mathrm{LD}_{50}$ values in mice were approximately $0.14 \mu \mathrm{g} / \mathrm{mL}$ and $0.32 \mu \mathrm{g} / \mathrm{mL}$, respectively (25). Moreover, in the current study it was noted that $H$. magnifica had a significant effect $(p<0.05)$ on A431 and A549 cells at a dose of $40 \mu \mathrm{g} / \mathrm{mL}$.

It has been reported that the actinoporin RTX-A isolated from $H$. crispa exerted a significant cytotoxic effect on several human cancer cell lines, including HL-60, MDAMB-231, Hela, THP-1 and SNU-C4 at $10^{-9} \mathrm{M}$ (14). Consistent with this observation, there was significantly diminished viability of A549 cells by $H$. crispa in the current study. Malpezzi et al. (26) reported that Bunodosoma caissarum, which presents antimitotic activity, was fractionated by partition and adsorption on silica gel to identify the active substances. N-butanol from lipid fractions was tested on T47D cells at concentrations ranging from 50 to $500 \mu \mathrm{g} / \mathrm{mL}$. The cells showed a dose-dependent inhibition of cell proliferation. Consistent with this, $H$. malu and $C$. adhaesivum produced a significant effect on T47D at $40 \mu \mathrm{g} / \mathrm{mL}$. In contrast, T47D was not 
significantly affected by $H$. crispa, $H$. magnifica or E. quadricolor toxins.

In conclusion, this study has shown that different sea anemone venoms have varying cytotoxic effects on different cancer cell lines. Of the three cell lines tested, A549 was the most sensitive to killing by the venoms. A431 was vulnerable to killing by venoms from $H$. malu, H. magnifica, C. adhaesivum and E. quadricolor whereas T47D was susceptible to those from H. malu and C. adhaesivum. Currently, the purification and action mechanism of samples are being investigated in our laboratory. It is hoped that this investigation on bioactive compounds could provide leads for effective novel anticancer drugs.

\section{COPYRIGHT}

(c) CEVAP 2012

\section{SUBMISSION STATUS}

Received: July 14, 2011.

Accepted: November 21, 2011.

Abstract published online: November 28, 2011.

Full paper published online: May 31, 2012.

\section{CONFLICTS OF INTEREST}

The authors declare no conflicts of interest.

\section{FINANCIAL SOURCE}

A Faculty of Health Sciences Underwriting Grant provide partial financial support for this work.

\section{CORRESPONDENCE TO}

Barbara J. S. Sanderson, Department of Medical Biotechnology, School of Medicine, Flinders University of South Australia, Bedford Park, SA 5042, Australia. Phone: +61872218556. Fax: +61872218555. Email: Barbara.Sanderson@ flinders.edu.au.

\section{REFERENCES}

1. Karthikayalu S, Rama V, Kirubagaran R, Venkatesan R. Characterization, purification and phylogenetic analysis of a cytolysin from the sea anemone Heteractis magnifica of the Indian Ocean. J Venom Anim Toxins incl Trop Dis. 2010;16(2):223-40.

2. Bosmans F, Tytgat J. Sea anemone venom as a source of insecticidal peptides acting on voltage-gated $\mathrm{Na}+$ channels. Toxicon. 2007;49(4):550-60.

3. Kobayashi M, Hattori A. Spacing pattern and body size composition of the protandrous anemonefish Amphiprion frenatus inhabiting colonial host anemones. Ichthyol Res. 2006;53(1):1-6.
4. Anderluh G, Macek P. Cytolytic peptide and protein toxins from sea anemones (Anthozoa: Actiniaria). Toxicon. 2002;40(2):111-24.

5. Honma T, Shiomi K. Peptide toxins in sea anemones: structural and functional aspects. Mar Biotechnol (NY). 2006;8(1):1-10

6. Kem WR. Properties and effects of natural toxins and venoms. In: Williams PL, James RC, Roberts SM, editors. The principles of toxicology: environmental and industrial applications. 2nd ed. Hoboken, NJ: John Wiley and Son; 2003.

7. Burke WA. Cnidarians and human skin. Dermatol Ther. 2002;15(1):18-25.

8. Andreev YA, Kozlov SA, Koshelev SG, Ivanova EA, Monastyrnaya MM, Kozlovskaya EP, et al. Analgesic compound from sea anemone Heteractis crispa is the first polypeptide inhibitor of vanilloid receptor 1 (TRPV1). J Biol Chem. 2008;283(35):23914-21.

9. Gordon D, Martin-Eauclaire MF, Cestèle S, Kopeyan C, Carlier E, Khalifa RB, et al. Scorpion toxins affecting sodium current inactivation bind to distinct homologous receptor sites on rat brain and insect sodium channels. J Biol Chem. 1996;271(14):8034-45.

10. Tejuca M, Pérez-Barzaga V, Pazos F, Álvarez C, Lanio ME. Construction of sea anemone cytolysin-based immunotoxins for selective killing of cancer cells. Rev Cub Física. 2009;26(1):15-22.

11. Kem WR, Pennington MW, Norton RS. Sea anemone toxins as templates for the design of immunosuppressant drugs. Perspect Drug Discov Des. 1999;15/16(1):111-29.

12. Veeruraj A, Arumugam $M$, Ajithkumar $T$, Balasubramanian T. Isolation and biological properties of neurotoxin from sea anemone (Stichodactyla mertensii, S. haddoni). Internet J Toxicol. 2008;5(2).

13. Marino A, Valveri V, Muià C, Crupi R, Rizzo G, Musci $\mathrm{G}$, et al. Cytotoxicity of the nematocyst venom from the sea anemone Aiptasia mutabilis. Comp Biochem Physiol C Toxicol Pharmacol. 2004;139(4):295-301.

14. Fedorov S, Dyshlovoy S, Monastyrnaya M, Shubina L, Leychenko E, Kozlovskaya E, et al. The anticancer effects of actinoporin RTX-A from the sea anemone Heteractis crispa (=Radianthus macrodactylus). Toxicon. 2010;55(4):811-7.

15. Sencic L, Macek P. New method for isolation of venom from the sea-anemone Actinia cari. Purification and characterization of cytolytic toxins. Comp Biochem Physiol B.1990;97(4):687-93.

16. Walker JM. The bicinchoninic acid (BCA) assay for protein quantitation. Methods Mol Biol. 1994;32(1):58 .

17. Smith PK, Krohn RI, Hermanson GT, Mallia AK, Gartner FH, Provenzano MD, et al. Measurement of protein using bicinchoninic acid. Anal Biochem. 1985;150(1):76-85.

18. Mosmann T. Rapid colorimetric assay for cellular growth and survival: application to proliferation and cytotoxicity assays. J Immunol Methods. 1983;65(12):55-63.

19. Young FM, Phungtamdet W, Sanderson BJ. Modification of MTT assay conditions to examine 
the cytotoxic effects of amitraz on the human lymphoblastoid cell line, WIL2NS. Toxicol in Vitro. 2005;19(8):1051-9.

20. Kueng W, Silber E, Eppenberger U. Quantification of cells cultured on 96-well plates. Anal Biochem. 1989;182(1):16-9.

21. Saotome K, Morita H, Umeda M. Cytotoxicity test with simplified crystal violet staining method using microtitre plates and its application to injection drugs. Toxicol In Vitro. 1989;3(4):317-21.

22. Soletti RC, de Faria GP, Vernal J, Terenzi H, Anderluh G, Borges HL, et al. Potentiation of anticancer-drug cytotoxicity by sea anemone pore-forming proteins in human glioblastoma cells. Anticancer Drugs. 2008;19(5):517-25.
23. Standker L, Béress L, Garateix A, Christ T, Ravens U, Salceda E, et al. A new toxin from the sea anemone Condylactis gigantea with effect on sodium channel inactivation. Toxicon. 2006;48(2):211-20.

24. Shiomi K, Honma T, Ide M, Nagashima Y, Ishida M, Chino M. An epidermal growth factor-like toxin and two sodium channel toxins from the sea anemone Stichodactyla gigantea. Toxicon. 2003;41(2):229-36.

25. Khoo KS, Kam WK, Khoo HE, Gopalakrishnakone P, Chung MC. Purification and partial characterization of two cytolysisns from a tropical sea anemone, Heteractis magnifica. Toxicon. 1993;31(12):1567-79.

26. Malpezzi ELA, Matsui DH, Groote SCTS, Freitas JC, Santelli GM, Fernandes JB. Antitumoral activity in an organic extract of the sea anemone Bunodosoma caissarum. Toxicon. 1995;33(3):291. 